\title{
From Cotton Trader to Investment Banker: $1844-2008$
}

\begin{abstract}
A brief history
On 29 January 2008, Lehman Brothers Holdings Inc reported record revenues of nearly $\$ 60 \mathrm{bn}$ and record earnings of over $\$ 4 \mathrm{bn}$ for its fiscal year ending 30 November 2007. Just eight months later, on 15 September 2008, Lehman Brothers sought Chapter 11 protection in the largest bankruptcy ever filed. Its collapse sent shock waves around the world. Everyone remembers the name, Lehman Brothers. Many regard its collapse as the cause of 2008's financial crisis.

The later stages of the existence of Lehman Brothers were dominated by Dick Fuld, one of the longest-serving chief executives on Wall Street. Fuld's dominance of the company, which he had built up and which he regarded as almost a personal possession, was one of the causes of its ultimate failure.

Lehman Brothers' long history began with three brothers, immigrants from Germany, setting up a small shop in Alabama, selling groceries and dry goods to local cotton farmers. Their business soon evolved into cotton trading. Henry, the eldest brother, died at the age of 33 in 1855; the two younger brothers headed the firm for the next four decades. The firm began to expand, setting up a commodities trading business in New York in 1858. That gave Lehman a foothold in Manhattan's financial community, a fact which was of especial importance after the Civil War, when the firm had to rebuild itself, selling bonds for the state of Alabama, servicing that former Confederate state's debt and interest payments. In 1870 Lehman Brothers led the way in the formation of the New York Cotton Exchange, the first commodities futures trading venture. Mayer Lehman was appointed to the Cotton Exchange's first board of directors. Lehman Brothers' commodities futures trading business grew to include other goods, and the firm also helped to set up the Coffee Exchange and the Petroleum Exchange.

This was followed in the 1880s and 1890s by Lehman Brothers' development of the Southern railroad system, just as JP Morgan and Kuhn Loeb led the
\end{abstract}


financing of the Northern railways. Lehman observed the trend of issuing bonds to raise capital, and expanded its commodities business to include the trading of securities.

Raising capital during the Great Depression and the 1930s was obviously extremely difficult. Lehman was one of the first firms to develop a new form of financing, now a standard practice known as private placement. The loans between blue-chip borrowers and private lenders included strict safeguards and restrictions concerning lender safety, enabling borrowers to raise much-needed capital and lenders to receive a suitable level of return. Lehman Brothers continued to be an innovative firm, willing to take the risks of investing in new areas of commerce. It was one of the early backers of retail firms such as Sears, Woolworth's and Macy's, and then the entertainment industry, including 20th Century Fox and Paramount Pictures. The company then turned to oil, financing the TransCanada pipeline, and oil servicing companies such as Halliburton. When electronic and computer technology became drivers of the economic expansion of the 1950s, there was Lehman, still seeking investment opportunities. In the 1960s, Lehman Brothers developed its capital market trading capacity, especially in commercial paper. It became the official dealer for US Treasuries. ${ }^{1}$

The last member of the Lehman family to have actively led the company (which he did from 1925), Robert Lehman, died in 1969, having steered it through an important period of growth in a period in which new developments had dramatically changed the world. Lehman began to expand globally, opening offices in Europe and Asia, eventually merging with a leading investment bank, Kuhn, Loeb \& Co. Following the death of Robert Lehman, the firm struggled under the leadership of Frederick Ehrman, who had been at Lehman Brothers since World War II. He was replaced by Peter Peterson, a former US Secretary of Commerce in the Nixon administration, who had little experience of banking, still less as a trader. Nevertheless, he turned the company around, and in the last five years of his stewardship the company became extremely profitable. His chief problem was Lew Glucksman, head of trading, who worked long hours and regarded the bankers (as opposed to the traders) with disdain. Peterson tried to keep Glucksman on-side but neither the additional bonuses nor shared leadership prevailed. Glucksman wanted to run the firm himself, but patently lacked the skills to do so, appointed his own people to important positions, pushed out some partners from the seventy-seven and others decided to go, each taking their capital with them. Dick Fuld, Glucksman's protégé, was in charge of all trading, but was unable to answer questions about his strategy at partners' meetings. 
Glucksman had been determined to take over the firm, but

it did not seem to occur to him that he did not have the skills... He put his own people in the firm's important position ... The biggest bonuses went to Glucksman and Fuld with \$1.6 million each. He pushed some partners out, while others decided to go, taking their capital with them. If many more went, Lehman Brothers would have little capital to work with. ${ }^{2}$

Glucksman had put Dick Fuld in charge of all trading.

At a meeting called to discuss the key issue of capital, Fuld was asked how he could help boost capital in the future.'How did you make money in your trading operations over the last five years, and how are you planning to make money over the next several years?' asked one partner. 'I don't know how I made it over the last five years', he replied. He was also unclear about the future. He had 'hired some people to study the matter. ${ }^{3}$

Glucksman tried to explain it all away by saying that Fuld had difficulties with communication. It seems that he did not learn all that much more about communication, from all accounts. Fuld was subsequently described as the 'Gorilla', intimidating people by his height, appearance and sometimes inarticulate responses.

As partners left the company, the remaining partners pushed Glucksman into looking for a partner with capital. That, however, was only part of the story. Glucksman and Peterson were jointly running Lehman Brothers, but, it seems, Glucksman's resentment and anger with Peterson grew and intensified over time, as well as his ambition.

It irritated him when Peterson said ... I didn't have a detailed grasp of that part of our business that was increasingly important - trading, futures, brokerage, commodities. This angered Glucksman because these trading functions were then generating two-thirds of Lehman's profits. And now that trading was getting its day in the sun, he feared Peterson was angling within a few years to sell the firm for a substantial premium over the current share price. ${ }^{4}$

The two men were the same age, and both would be obliged to sell their stock when they reached the age of 60 . Glucksman fought on and eventually forced Peterson to sell and retire. Glucksman himself only lasted a few months at the helm. In effect he was forced to find a buyer, because rumours began to circulate and were published in Fortune to the effect that Lehman Brothers were 'peddling 
the firm?. If the rumours persisted they would be forced to sell the firm for a fraction of its real value.

American Express was there to take Lehman Brothers on, having recently purchased Shearson, a large brokerage rather than an investment bank. Lehman Brothers would add a touch of class to the new company. In 1984, Glucksman made $\$ 15 \mathrm{~m}$. by selling his shares, and set up his own consultancy in Wall Street. Glucksman and others had destroyed Lehman's independence. Dick Fuld was bitterly disappointed at the American Express takeover, but stayed on as head of trading. The new company then merged with EF Hutton in 1987 with a combined net value of $\$ 1 \mathrm{bn}$, becoming Shearson Lehman Hutton. During that period, the firm aggressively built its leveraged finance business. But Harvey Golub, who became the CEO of American Express in 1993, began to divest the company of its investment and broking arms. Shearson's was sold to Primerica, the precursor of Citigroup, merging with its retail broking business. American Express also disposed of Lehman Brothers with a little capital, having finally recognized that it never sat well with the credit card company. American Express announced to the world at large that it would inject $\$ 1.09 \mathrm{bn}$ to make the newly independent firm financially viable and ensure that it had an A rating. In exchange, American Express would have a share of Lehman's profits and Lehman's employees would pay $\$ 160 \mathrm{~m}$. for newly issued shares, so that the total capital infusion would be $\$ 1.25 \mathrm{bn} .^{5}$

However, Fuld had run the trading division so successfully that when American Express divested itself of the company, the CEO asked him to take over running it as Chairman and CEO. Lehman Brothers emerged as a limited company in 1994, rather than a partnership. Fuld did not want any repetition of in-fighting between partners, which had caused so much damage in the past when partners were leaving the company taking their capital with them. Fuld insisted that the firm's employees had to take a large amount of their salary and bonuses in shares, which they would not be able to sell for several years.

Lehman Brothers had regained its independence, but if it was to retain this independence, given the extent of its losses and assailed as it was by many rumours of takeover throughout the 1990s, then changes would have to be made. Fuld began the process of restructuring the company so that it consisted of three major operating units: investment banking, equities and fixed income. He refocused the company's activities on high-margin business such as mergers and acquisitions, bringing in experienced senior staff to manage the business. This was reinforced by the compensation arrangements in January 1997, when Fuld 
approved $\$ 48 \mathrm{~m}$., of which only $\$ 2.4 \mathrm{~m}$. was for fixed income, with the rest for the equities, investing and banking divisions in January 1997. Changing the company's focus and image for the outside world took time.

The new company had a narrow range of offerings. Its share trading had declined after the 1987 stock market crash. It was without a wealth management unit. Its income from banking came from arranging company takeovers and was $\$ 800 \mathrm{~m}$. a year, whereas its trading department brought in double that. Chapman notes that it had one feature which would be significant in the future. It was second only to Morgan Stanley in selling mortgage bonds. ${ }^{6}$

In another portent for the future, Lehman extended the range of its business activities by moving into commercial real estate. Mark A Walsh was Lehman's head of global real estate in 1997. He was widely regarded as Wall Street's most successful property financier, having arranged some very large deals in 1997. ITT Corporation, which concentrated on hotel and gaming businesses, had been Lehman's client for a long time, and was then up for sale. Barry Sternlicht, head of Starwood Hotels and Resorts, wanted to buy ITT, but needed to raise $\$ 7 \mathrm{bn}$ very quickly, otherwise he would lose the deal. Walsh promised him that it would be done, but Sternlicht still needed reassurance. Later, Sternlicht said: 'Dick Fuld sat there in my living room and said, "You have our word. It will be done"."7 Lehman beat Goldman Sachs to the deal, earning $\$ 20 \mathrm{~m}$. as the fee. During that year, Walsh made other important deals, such as the sale of the Chrysler and Woolworth Buildings. He was to continue with deals of that nature, ignoring the fall in commercial real estate prices until 2008.

Fuld successfully steered his company through the Asian financial crisis, the collapse of Long Term Capital Management and 9/11, when Lehman lost its headquarters but almost all of Fuld's staff survived. When Lehman Brothers moved to their new headquarters in 2002, the chief operating officer at the time, Bradley H Jack, grouped the bankers by industry group, so that bankers specializing in everything from stocks to bonds and convertibles worked alongside each other in 'pods', each representing a different industry. The aim was to ensure that bankers working for the same client communicated with each other and were in a position to offer creative solutions. 'Before the spin-off in 2004', Fuld told Business Week, 'success was measured by what each individual accomplished. Today, it's all about the team.' That is the way in which he viewed his management style.

He gained the support of his staff by keeping their salaries in line with earnings. The ratio of compensation costs to gross revenues remained at 51 per cent. 
Even in 2001, Lehman allocated $\$ 544 \mathrm{~m}$. for stock-based pay, which accounted for 15.8 per cent, as compared with the 6.4 per cent allocated for employees at Merrill Lynch. Fuld's message to new recruits was that if they joined the firm, he would make them rich, perhaps seriously rich. The strategy which Dick Fuld and Bradley Jack developed in the aftermath of 9/11 began to pay off in the summer of 2002. Business Week recorded what happened when Williams Cos, an energy trading company facing bankruptcy, asked for Lehman's assistance in raising \$3.4bn. Hugh 'Skip' McGee, then head of Lehman's energy-banking group in Houston, with a team of 30 bankers, worked night and day to raise enough capital by selling assets such as pipelines and arranging finance from Warren $\mathrm{E}$ Buffett and banks secured by natural gas reserves. They saved the company. McGee then moved to New York as head of investment banking, where he continued to develop the policy of rewarding his bankers for finding solutions for clients, instead of selling products. Staff were constantly reminded that 'investment banking is a team sport - use all the resources'. McGee's policy seemed to work, since net income increased 74 per cent to $\$ 1,699 \mathrm{~m}$. in 2003 , and Lehman's share price rose from $\$ 53.29$ to $\$ 79$ at one point, ending the year at $\$ 77.22$.

Something of Fuld's commitment to his work was demonstrated in an article in Bloomberg's Business Week:

It was late December but the holidays were not on the mind of Lehman Brothers Inc Chairman and Chief Executive, Richard S Fuld Jnr. On his desk, next to a tall Starbucks Mocha Frapuccino, was a list of hundreds of banking clients. He was determined to reach every person by New Year's Day. 'When something is on my list', he said, 'it will get done."

He reached almost everyone. Lehman Brothers had advised on \$99bn in US mergers and acquisitions announced last year, increasing its market share by an enormous 6.2 per cent to 18.9 per cent. Lehman had beaten Credit Suisse First Boston, Merrill Lynch and JP Morgan Chase, putting the company in fourth place, up from ninth in 2002. In 2002, Lehman also raised \$314bn in debt and equity issues for companies, making it the No 2 underwriter of securities in the USA. Moody's was quoted as saying that, 'It is a much more diversified shop than it was five or six years ago, and it operated in an extremely disciplined fashion'.

Lehman was often described, dismissively, as a 'bond house', low in the Wall Street pecking order. That remained true in a sense. 'He chose to exploit that area of strength, building the firm into a fixed income juggernaut and benefitting 
mightily from the seismic decline in interest rates over the past decade. Today, Lehman derives 48 per cent of its revenue from fixed income.9 At the same time, however, when Lehman advised AT\&T on its $\$ 89 \mathrm{bn}$ acquisition of BellSouth, it brought in its capital-market experts to advise on financing, share buybacks and liability management. 'Richard Fuld personally committed his time and all the resources of the firm to us, and that made a big impression', said AT \& T CEO, Ed Whitacre. ${ }^{10}$ The article also quotes one of Fuld's former colleagues, who said that, 'People talk about how successful Dick has been and the great job he has done, and that's all true. But what I find amazing is how he had learned and mastered every part of this business.' Doubts had been expressed about the fixed income business without a falling interest rate environment. Dave Goldfarb, Lehman's chief administrative officer pointed out that in 2000, there was $\$ 16$ trillion of global fixed-income securities; in 2005, that increased to $\$ 27$ trillion, and in 2009, he expected that number to climb to $\$ 38$ trillion.

Perhaps here lies a hint of troubles to come: an over-optimistic view of the future. All would be to Lehman's advantage.

\section{Lehman's acquisitions}

\section{Acquisitions in 2003}

At the same time, Fuld made a series of acquisitions, designed to lessen Lehman's dependence on fixed-income trading, and focus attention on mergers and acquisitions, investment banking and raising capital. The purchase of Neuberger Berman in 2003 was designed both to rescue Lehman from the volatility of the bond trading market and to establish its position as a leading Wall Street firm. Morgan Stanley, Merrill Lynch and Goldman Sachs already had significant money management operations, regarded as an essential element of an elite Wall Street firm. Neuberger Berman had $\$ 63.7 \mathrm{bn}$ under management, a respected range of funds and wealthy clients. The deal was completed at the end of 2003, giving Lehman Brothers $\$ 100$ bn under management, but still far below its main rivals, Merrill Lynch, Goldman Sachs and Morgan Stanley. Neuberger Berman had been founded by Roy R Neuberger in 1939, and the sale was agreed on his 100th birthday. At least its employees were about to join an even older firm, and Fuld also sought to retain as many of its employees as possible, setting aside a bonus pool of $\$ 120 \mathrm{~m}$. as well as seeking to ensure that the 30 top fund managers stayed with the firm by having them sign a three-year non-compete agreement 
and restricting the amount of shares they could sell. The plan apparently worked, since as part of the bankruptcy proceedings, Neuberger Berman's senior executive team and its fund managers took the company back again in a management buy-out in December 2008.

In 2003, however, Fuld's purchase was designed to enable the company to diversify its sources of revenues, with fee-based income expected to account for 21 per cent of its revenues, up from 13 per cent, and cost savings and revenue gains to total $\$ 50 \mathrm{~m}$. in 2004 and $\$ 100 \mathrm{~m}$. in 2005 as the business and back-office operations were combined. During a conference call, Fuld explained to the New York Times that 'Neuberger Berman is one of the largest and most respected, independent, high net worth managers. When Neuberger is combined with our existing wealth and asset management group, Lehman Brothers will emerge as one of the leading providers to a highly desirable marketplace."11

The extent to which those expectations were realized is revealed in the quarterly report for the last quarter of 2003 and the annual report for 2004. The description of the company's activities reflected both the move away from fixed income trading, and Fuld's ambitions for Lehman Brothers. The 'customer flow model' was based on the company's principal focus of facilitating client transactions in all major global capital markets, products and services. Customer flow revenues were generated from institutional and high net worth clients by (i) advising on and structuring transactions specifically suited to meet client needs; (ii) serving as a market-maker and/or intermediary in the global marketplace, including having securities and other financial instrument products available to allow clients to rebalance their portfolios and diversify risks across different market cycles; (iii) providing asset management services; and (iv) acting as an underwriter to clients. The investment management business segment consists of the private investment management, with fees from high net worth clients and asset management business lines. The latter generates fees from customized investment management services for high net worth clients and asset management fees from institutional investors and others. By the end of the financial year in November 2004, the total net revenues from these two sources had increased by 87 per cent to $\$ 1,694 \mathrm{~m}$. from $\$ 907 \mathrm{~m}$. in 2003 , justifying the purchase of Neuberger Berman.

In 2003, Lehman purchased the Crossroads Group and Lincoln Capital Fixed Income. The aim was to boost Lehman Brothers' global private equity franchise to about $\$ 7 \mathrm{bn}$ in private equity assets under management. Another aim was to strengthen Lehman's position as a leader in private equity management. Michael Odrich, global head of Lehman Brothers Private Equity Division, stated that it 
emphasized the firm's commitment to expanding its private equity and asset management franchise. Lincoln Capital was acquired to be part of the wealth and asset management group. All three acquisitions were essential, in Fuld's mind, to end the company's dependence on fixed income markets, enabling it to offer a variety of services and to be seen as an equal, if not more so, of Goldman Sachs, JP Morgan, Merrill Lynch and Bear Stearns.

At that time, critics thought that the then expected downturn in the bond market would show that Lehman still had not ended its dependence on the fixed income market. But Blaine A Frantz, a senior credit officer at Moody's told Business Week, 'It is a much more diversified shop than it was five or six years ago, and is operated in an extremely disciplined fashion.12 The final results for 2003 showed that Lehman had advised on \$99bn in US mergers and acquisitions, raising its market share by 6.2 per cent to 19 per cent, putting it in fourth place, up from the ninth place (and overtaking Merrill Lynch and JP Morgan Chase). The company also became the second largest securities underwriter in 2003, up from fourth in 2002.

\section{Acquisitions in 2004}

Acquisitions did not stop there. In 2004, Lehman purchased California-based BNC Mortgage, having already taken a stake in the company in 2000. Other acquisitions included Finance America LLC (which merged with BNC in 2005) and Aurora Loan Services LLC, which it acquired in 1997. BNC Mortgage specialized in making subprime loans, while Aurora Loan Services specialized in Alt-A loans, that is, loans made to borrowers without full documentation. In the first half of 2007, Aurora originated over $\$ 3 \mathrm{bn}$ a month of such loans. Through BNC Mortgage, Lehman stood at No 11 in a list of 25 subprime lenders with a loan volume of \$47.6bn between 2005 and 2007.

In addition to owning subprime lenders, Lehman was also a leading underwriter for subprime mortgages for other companies, to the tune of some \$221bn between 2000 and 2007. In August 2007, Lehman announced that it was closing BNC Mortgage, although it would continue to make loans through its subsidiary, Aurora Loan Services. With regard to BNC, Lehman gave as its reasons, the 'poor market conditions', which necessitated 'a substantial reduction in its services and capacity in the subprime space'. In its regulatory filing for the three months ending on 31 May 2007, Lehman said it had 'unrealized' losses of $\$ 459 \mathrm{~m}$. but that these losses were offset by gains in corporate bond and equity holdings as well as derivative contracts. 


\section{Acquisitions and developments in 2005}

Mortgage loans were not the only area into which Lehman Brothers expanded during those two significant years, 2006 to 2007. Established in February 2005, Ospraie had become one of the leading specialist commodities funds, and Lehman had taken a 20 per cent stake in the fund from the beginning. Lehman had the rights to 20 per cent of Ospraie's profits and access to the investment opportunities the fund would provide. In return, Ospraie had access to Lehman's prime brokerage and other trading opportunities.

These developments were all part of Fuld's strategy. In July 2005, in an interview with Euromoney, he stated, 'What we focus on in the executive committee is increasing our revenues from around $\$ 12 \mathrm{bn}$ to $\$ 15 \mathrm{bn}$ or $\$ 20 \mathrm{bn}$, and indicated that such gains might come from 'a strong acquisition'. Despite the efforts to increase diversity, Lehman still earned about 60 per cent of its revenues from the fixed income business, whereas for Bear Stearns the figure was 50 per cent, and for Merrill Lynch 25 per cent. The article stressed that Lehman's fixed-income business was one of the strongest and most diversified on Wall Street, which, 'combined with the bank's more conservative approach to risk management, helped it to report solid second quarter earnings in the face of severe dislocation in the markets'.

Fuld also stated in the article that his staff were expected to have as much responsibility for how the company was run as he had. 'I expect everyone at the firm to be a risk manager', and for all twelve members of the executive committee: 'All twelve of us are focussed on all parts of the business. It's all about risk management. If it's just about me, then we're in trouble.'This interview took place before Fuld adopted what has been described as a more 'aggressive business strategy', but some of the groundwork had already been carried out in 2005 . During the course of the interview, he was asked why, although Lehman was already a large underwriter of mortgage-backed securities, the company had invested in mortgage origination platforms and that 55 per cent of the MBS deals came from their own mortgage platform. Fuld replied that adding mortgage originations created a fully integrated business for the firm from a captive source for generating mortgage loans. It also provided additional fees and ensured quality control, so that loans were underwritten to appropriate standards. By 2005, Lehman realized that it was missing the vast profits other Wall Street banks were making by slicing residential mortgages and selling them on to investors as mortgage-backed securities or collateralized debt obligations, ignoring warnings about the growth of subprime mortgages. Lehman took comfort from the fact 
that they had the largest portfolio of commercial real estate on Wall Street. The firm regarded itself as an expert in financing commercial real estate, but it had paid high prices just before prices of commercial real estate began to decline. But management continued to take an optimistic view that this market was safe, in spite of the emerging evidence to the contrary - with disastrous consequences.

Rather than the major acquisition hinted at in the Euromoney article, Fuld turned to what seemed a lucrative and growing market: subprime loans. As the housing market strengthened, the strategy looked robust as Lehman turned more loans into mortgage-backed securities. In 2006, Lehman made a deliberate business decision to pursue a higher growth strategy, as he had already stated in the Euromoney interview. To achieve this objective, and noting that his main competitors had increased their revenues through the subprime mortgage market, Lehman moved away from a low-risk brokerage model to a higher-risk capital-intensive banking model. The groundwork for this had already been done through BNC Mortgage and Aurora and by the purchase of mortgage origination platforms. The switch may not therefore have been as drastic as it has sometimes been presented. Before 2006, Lehman acquired assets to 'move' them to third parties as mortgage-backed securities, but in 2006 Lehman started to retain the assets, both residential markets and commercial real estate, as its own assets. The risk and return remained with Lehman.

The effects of this policy were that Lehman had to continually roll over its debt because of the mismatch between short-term debt and long-term illiquid assets. The company had to borrow billions of dollars on a daily basis. Its business risk was increased because of its investments in long-term assets - residential and, especially commercial real estate, private equity and leveraged loans. To provide for this growth in risk, a 13 per cent growth in revenues and an even faster (15 per cent) increase in its balance sheet and total capital base was required. In late 2007 , the company held assets of $\$ 700 \mathrm{bn}$ on equity of $\$ 25 \mathrm{bn}$ with $\$ 675$ bn of liabilities, most of which was short-term. As the subprime crisis began to develop, Lehman trebled its holdings in illiquid investments from $\$ 87$ bn in 2006, to $\$ 275$ bn at the end of the first quarter of 2008.

Why did Fuld decide to pursue this aggressive growth strategy at that point in time? The company had grown and developed remarkably under his leadership since he took over as Chairman and CEO in 1994. He had been named 'Best CEO' in 2004 by Institutional Investor. One long-standing former director at Lehman Brothers said that Fuld seemed determined to change from his familyorientated and relatively modest lifestyle (despite his millions, he did not own a yacht or a private jet, and went to the same part of Italy with family every year), 
and wanted to join the very rich club. That change also apparently affected his approach to management, becoming more detached and dictatorial. He had been described by many on Wall Street as an 'unbelievable competitor,'obstinate, determined and unaccountable' and by others as 'obstinate, confrontational and blunt'. His nickname was indeed the 'Gorilla', which he seemed to enjoy. He was often criticized by former employees for being remote, staying on Floor 31 of the headquarters in New York's 7th Avenue, where he and his No 2, Joe Gregory, discussed the business 'at least 20 times a day'. Andrew Gowers, who left the Financial Times to become Lehman's head of corporate communications in London in 2006, noted that

Fuld had become insulated from the day-to-day realities of the firm and had increasingly designated operational authority to his number two, a long-standing associate [President and Chief Operating Officer Joe Gregory], who was not a detail man or a risk manager, who actively urged divisional managers to place even more aggressive bets in surging asset markets such as mortgage business and commercial real estate. ${ }^{13}$

By the third quarter of 2007, Lehman Brothers had some thirty-five guaranteed subsidiaries in all the major markets, employing about 30,000 staff worldwide, including around 10,000 at the head office in New York. That was quite different from the early days of Fuld's tenure as Chairman and CEO, when he had only twenty-two managers reporting to him. He knew the staff at headquarters individually, was often seen in the trading rooms and was accessible to his staff. As Lehman Brothers grew, that inevitably meant that Fuld's commitments, both in travelling to set up new offices or new subsidiaries, meetings and interviews, took up so much of his time that the camaraderie and personal oversight of the trading room had gone. Many employees had worked at Lehman Brothers for a long time, and they remembered the sense of belonging to a family, which Lehman encouraged. It also involved its employees in the company through the 'culture of ownership', in which staff received a disproportionately high percentage of their pay in Lehman stock and options. When the firm went public, employees owned 4 per cent of the firm worth about $\$ 60 \mathrm{~m}$., but by 2006 , they owned about 30 per cent equivalent, equivalent to $\$ 11 \mathrm{bn}$. Of course, by September 2008 their shares were worthless.

Between 1994 and 2007, Lehman Brothers' market capitalization increased from $\$ 2 \mathrm{bn}$ to $\$ 45 \mathrm{bn}$, and its share price went from $\$ 5$ to $\$ 86$, providing shareholders with an average annual return for shareholders of 24.6 per cent. It grew to 26,200 employees, with more than 60 offices in over 28 countries by the 
third quarter of 2007. It is small wonder that any sense of belonging to a family disappeared, with the exception of a small band of senior executives who met together on Friday mornings. That could be part of the reason for the perception that Fuld was remote and inaccessible on Floor 31. One of his former executives indicated that, apart from the inevitable increasing burden of meetings for any CEO of a global company, the firm itself may have grown beyond the capacity and management skills of the CEO. For Fuld, in particular, it may have been especially difficult to realize that the management of the company he had built up was perhaps beyond the capability of one man, since he had devoted his life's work to that task, and had succeeded in keeping the company going when many thought it would fail through extremely difficult times. Instead of being 'too big to fail', the time had come to consider the risk that a global bank with a vast network of subsidiaries, many of which focused on different aspects of financial services, might have become 'too big to manage', unless the management structure was well-designed with clear reporting lines and highly competent managers at every level. Much more work needed to be done to find ways of making the inevitable pyramid structure function effectively. 
Oonagh McDonald - 9781526100580 Downloaded from manchesterhive.com at $04 / 26 / 2023$ 10:49:43AM via free access 